Chapter 6

\title{
Lactation Responses toward Milk Indigenous Enzymes
}

\author{
Aneela Hameed, Majid Hussain and Saeed Akhtar
}

Additional information is available at the end of the chapter

http://dx.doi.org/10.5772/66392

\begin{abstract}
Milk being a highly nutritious food in its natural form provides energy. There are various factors influencing the composition of milk: breed, stage of lactation, nutritional status, health, and milking intervals. A number of indigenous enzymes present in milk are being affected by stages of lactation period. Their concentration varies during early, mid and late lactation periods. This varied behavior ultimately affects the quality of dairy products. In this chapter, the level of milk enzymes: lipases and esterases, plasmin (PL), plasminogen (PLG) phosphatases (alkaline phosphatase ALP; acid phosphatase (ACP), lysozyme (LZ), lactoperoxidase (LP), xanthine oxidoreductase (XOR), and catalase (CAT) will be reviewed with respect to the stages of lactation periods.
\end{abstract}

Keywords: milk, indigenous enzymes, lactation stages, parity, season

\section{Introduction}

Milk is one of the perfect, complete, and primitive dairy food known by mankind. It is white and nutritious physiological secretion from the mammary glands of mammals, serves as nourishment for their neonates [1, 2]. It is a major product obtained from healthy and highly productive dairy animals. Physiological and nutritional provisions of each species are more or less distinctive. The breed, health, nutritional status, stage of lactation period, and milking intervals are some of the factors that affect the milk composition [3, 4]. The variation in constituents occurs entire lactation period. Lactation stage is the prime factors that affect the 
milk properties and some of the enzyme activities [5, 6]. Solids-non-fat (SNF) content is frequently highest throughout first $2-3$ weeks of lactation.

\section{Milk indigenous enzymes}

Numerous enzymes have been indigenously identified in milk from 1924 to 1970 [7]. A large number of enzymes with multiple functionalities are present in milk. Additional enzymes contribute in quality of milk products and also perform an antibacterial action (LP). In bovine milk more than 70 enzymes are detected [8,9]. A 50-60 substantial number of milk enzymes with multiple functions are present in abundance in milk and are concerned with processing stability and general customer safety [10] and additionally processing suitability (ALP). Some enzymes (LP) having antibacterial characteristics are with significant importance in preservation of milk and milk products and some, e.g., plasmin (PL) and lipoprotein lipase (LPL) connected with the serum, plasma, fat globules, casein, or leukocytes are important in maintaining of quality of milk and milk products. More than 40 enzymes have been recognized in cow milk $[9,11]$.

Lactation period in animals involves colostrum, developed milk, peak, and production with compositional variations. Numerous indigenous enzymes present in milk are secreted by epithelial cells and their composition changes with the lactation stages.

In already recognized indigenous enzymes in milk [7], almost 20 enzymes have been well characterized and the rest of the 40 enzymes are of little significance but can be identified through their activity. These enzymes indicate the efficient process of milk pasteurization (ALP, $\gamma$-glutamyl transferase GGT) or of mastitis (phosphatases, CAT). Additional enzymes can be of significance in processing and ultimately providing safety to human beings. They play an antibacterial activity (LP) and contribute quality to milk products (e.g., LPL, PL) associated with the serum, plasma, fat globule, casein, or leukocytes.

\subsection{Lipases and esterases}

Lipolytic enzymes have capability to hydrolyze triacylglycerols are considered as carboxylesterases $[12,13]$. Those enzymes that can hydrolyze acyl glycerol having $<10$ carbon atom fatty acids are known as esterases or carboxylases (Enzyme Commission, EC 3.1.1.1) while those can hydrolyze $\geq 10$ carbon atom fatty acids are considered as lipases, or triacylglycerol acyl hydrolases (EC 3.1.1.3) [14, 15].

Esterases are different from lipases due to their functions for being relatively soluble compared to emulsified ester substrates. Several esterases are present in milk $[15,16]$, the most prominent are carboxylesterase (EC 3.1.1.1), acetylcholinesterase (EC 3.1.1.7), and cholinesterase (EC 3.1.1.8). In bovine colostrum, lipase is not connected with casein and not activated by blood serum, therefore exhibited low lipase activity and showed slight lipolysis in early lactation. However, after few days of calving, normal milk from early lactation exhibited higher lipase activity $[17,18]$. 
Lipases are naturally a critical group of enzymes since they are connected with the fat digestion system. Lipases are more dynamic at $\mathrm{pH} 8-9$ and catalyze the advancement of hydrolytic rancidity in milk. Investigation of lipases is more alluring in the light of the fact that it would add to our comprehension about the properties and modes of these enzymes $[19,20]$.

The phenomenon of lipolysis is correlated with the lactation days. Higher activity is associated with its presence in fat fraction of milk. Activity of lipase in milk fat increases with the advancement in lactation stages [21]. The lipolysis process is of major apprehension in the dairy industry, as rancid off flavors are produced in milk and milk products during this phenomenon [22].

Earlier research has well established that milk lipase is sensitive to heavy metals. Copper, cobalt, and nickel have been shown to be more powerful inhibitors of lipase than iron, chromium, manganese, and silver. Enzyme activity is stimulated by blood serum albumin, ammonium, calcium ions, and mercaptoethanol. The buffer solutions, citrate, acetate, and phosphate buffers damage the enzyme activity, whereas borate and barbiturate buffers do not $[23,24]$.

LPL in cow milk is altered due to the breed, lactation phase, feed and fodder, season, and milk yield [22, 25]. Lipase activity increased from 0.32 to $2.98 \mathrm{U} / \mathrm{mL}$ of milk. At the point when milk fat globule membrane (MFGM) is damaged, lipolysis takes place rapidly and leads to hydrolytic rancidity and ultimately may cause variations in functionality and flavor of dairy products throughout storage period [15]. LPL found in goat milk is of low concentration in the early and late lactation stage [26].

The membrane lipase is available in higher concentration in milk from dairy animals in late lactation [27]. They additionally reported that lipase action in milk showed inclined pattern with reference to lactation stages. Hameed et al. [28] reported the expanding pattern of lipase activity with lactation stages in bovine milk. Lipase action $(1.55 \mathrm{U} / \mathrm{mL})$ was recorded higher $(p<0.01)$ in milk, examined at the last of lactation, followed by other lactations $(1.29$ and 1.16 $\mathrm{U} / \mathrm{mL}$, respectively).

\subsection{Plasmin}

Plasmin (PL; EC 3.4.21.7) is an alkaline serine proteinase enzyme that proteolytically cleaves the blood clots [29]. This enzyme has affinity toward arginine (Arg) and lysine (Lys) residues, specifically breaks the Arg-X and Lys-X bonds [30,31]. The activity of enzyme is increased with the multiple factors that include lactation stage, lactation number and severity of mastitis infection [32-34].

On the basis of origin, the PL and plasminogen (PLG) are considered to be migrated from blood to milk, and higher activity of PL in peak lactation designating more conversion of PLG into PL in bovine milk [35-37].

PL is basically released in the form of PLG in normal milk. The concentration of PLG (0.8-2.8 $\mu \mathrm{g} / \mathrm{mL})$ in fresh milk is varied and its concentration is $2-30$ times higher than that of PL $(0.1-$ $0.7 \mu \mathrm{g} / \mathrm{mL}$ ). It is activated by storage or when milk is stayed in the lumen of mammary glands 
before milking. A considerable interest has been involved in the activation of PLG, upon which activity of PL depends [38-41]. It promptly hydrolyzes the bonding of $\beta$-casein, $\alpha_{\mathrm{s} 2}$-casein, and $\alpha_{\mathrm{s} 1}$-casein and affects the quality of dairy products [32, 42].

Advancing lactation stage is an essential factor that influences PL activity and percentage, suggesting that more PL activity in milk from goat and older cows is a result of increased PLG activation [43-45]. However, the relevant information about the varied concentration and activity of PL during lactation stages is controversial. Leitner et al. [46] declared significantly higher activities of PL in infected glands of sheep.

Caroprese et al. [47] and Albenzio et al. [33] found that there was decrease in PL activity in ewe's milk from the early to the late lactation stage whereas Koutsouli et al. [48] and Bianchi et al. [49] announced that PL activity significantly affected by udder health status and found an increased level of PL activity due to more somatic cell counts (SCCs) during the late lactation period.

The variation in PLG-derived activity and total PL plus PLG-derived activity is greatly influenced by lactation stage and seasonal changes. It is linked with reduction of milk yield and advancement in lactation stage $[45,50,51]$. Due to increased activity of plasminogen, more entry of PL occurred from blood to milk inside the mammary glands [52]. The PL and PLG activities were significantly increased in the advancement of lactation and a nonsignificant decrease in their ratio (PL:PLG) was observed as compared to camel milk [53, 54].

\subsection{Phosphatases}

\subsubsection{Alkaline phosphatase}

In 1925, for the first time, phosphatase enzyme in milk is documented by Demuth and then considered as an alkaline phosphatase (ALP; EC 3.1.3.1) indigenous to milk by Graham and Kay [55]. It became recognizable when it was confirmed that the requirement for timetemperature relationships to inactivate the ALP required slightly higher as compared to kill Mycobacterium tuberculosis $[56,57]$. Almost $40 \%$ activity of ALP in raw cow milk is declared to be linked with the milk fat globule membrane (MFGM) in the cream phase, though the rest is soluble or dispersed in whey membrane particles (WMP) in skim milk [58]. Between individuals and herds, higher ALP levels vary significantly and its concerned activity is correlated with lactation stages and mastitis [59,60]. Magnesium and zinc ions are promoter of ALP while tin, copper, cobalt, and ethylenediaminetetraacetic acid (EDTA) have inhibitory action and iron has no effect on activities of ALP [61].

ALP activity is in inverse relationship with yield but the other factors, e.g., fat content, breed, and feed, have no effect. For ovine milk, the ALP content is contrarily linked with milk production and directly to the milk fat substance, while infected milk (mastitis) has higher ALP activity $[62,63]$. It is reported that ALP activity is low at the mature milk production stage, increased to maximum activity during the peak production stage and again decreased at the end production stage [28]. ALP activity in cow increases as lactation stage proceeds. Immediately after parturition, there is a decrease in ALP activity with a further sharp decrease after 
the first milking period. ALP activity then continues to decrease and noted minimum at the first week. Then increased slowly and found maximum by the 28th week of lactation [64]. In another study, ALP activity in milk was found lowest in the early lactation stages and progressed along with advancement of lactation stages and milk yields decreased. These ALP activities were also noticed greater in milk samples from evening milk as compared with morning milk [65].

\subsubsection{Acid phosphatase}

Acid phosphomonoesterase (ACP; EC 3.1.3.2) in milk was initially identified by Huggins and Talalay [66] and affirmed by Mullen [67], declared that ACP was ideally in the active form at $4.0 \mathrm{pH}$. It was thermally stable and for complete inactivation it required $88^{\circ} \mathrm{C}$ for $10 \mathrm{~min}$. ACP in bovine milk hydrolyzes the phosphate group of casein particles [68]. There are some components that act as inhibitor and activator. Fluoride acts as an inhibitor for ACP activity but slightly activated by $\mathrm{Mn}^{2+}$. In milk, the ACP level is just $2 \%$ that of the ALP level. Approximately $75 \%$ of ACP was found generally in the skim milk phase and $20 \%$ of ACP in the MFGM [68, 69]. Reducing agents, ascorbic acid and 2-mercaptoethanol increases the ACP activity by $100 \%$ in skim milk, whereas the ACP activity in MFGM is unaffected by these agents. Casein acts as a substrate for the activity of ACP and major casein fractions $\alpha \mathrm{s}(\alpha \mathrm{s} 1+\alpha \mathrm{s} 2)>\beta$ $>\kappa$ also serve as competitive inhibitors as the ACP enzyme binds with the phosphate group of casein. The ability to bind calcium with $\kappa$-casein to form micelles is reduced by dephosphorylation of casein [61].

ACP in milk might be of innovative significance due to three reasons. First, ACP exhibits thermal stability and because of this property it may be used as an indicator for severe heat treatment rather than normal. Second, numerous milk items may have a $\mathrm{pH}$ near to that of its optimum. Third, phosphoproteins such as caseins might be dephosphorylated readily. Technological milk properties and development of dairy products depend on the integrity of casein micelles. The enhanced activity of ACP may create problem in the inactivation of ACP without affecting nutritional qualities as it is linked with gelation of ultra-high temperature (UHT) and development of cheese flavor [70, 71].

Specific activity of ACP is greater in cream; however, about $80 \%$ ACP of milk is present in skimmed milk [60]. ACP levels in milk of Sahiwal dairy animals showed a declined pattern alongside lactation stages [28]. Shakeel-ur-Rehman and Farkye [72] observed the higher activity of ACP at 5-6 days postpartum, and afterward observed declined trend up to the end of lactation stage. Nevertheless, the range of ACP levels in their study was presented from 2.6 $\pm 10^{-4}$ to $2.6 \pm 10^{-3} \mathrm{U} / \mathrm{mL}$ in normal cow milk. The ACP level is $4-10$ times more in mastitis milk than normal cow milk $[73,74]$.

\subsection{Lysozyme}

Lysozyme (LZ; EC 3.2.1.17; muramidase) is a single polypeptide chain (14.3 KDa M.W.), crosslinked by four disulfide bonds $[75,76]$. It is an important bacteriolytic protein in milk, component of the antibacterial system, that kills bacteria by cleaving the $\beta-1,4$-glycosidic bond 
between $\mathrm{N}$-acetyl muramic acid and $\mathrm{N}$-acetyl glucosamine residues in peptidoglycan of the bacterial cell wall $[77,78]$.

It helps in improving the human health status, especially neonate, to protect them from infections of invading pathogens with the promotion of gut microbiota until their own immune system is developed [79-81].

Basically, there are two types of LZ: hen egg-white (C-LZ) and goose egg-white (G-LZ). However, both C-LZ and G-LZ forms may be present in cow milk as these forms are present in other body fluids and in stomach tissue of the cow [82].

$\mathrm{LZ}$ is available at higher concentration $(0.420 \mathrm{~g} / \mathrm{L})$ in human milk as compared to buffalos (3.85 $\mu \mathrm{g} / \mathrm{mL})$, cow $(0.0013 \mathrm{~g} / \mathrm{L})$, and goat $(0.0025 \mathrm{~g} / \mathrm{L})$ milk [83-86].

The activity of LZ was in greater extent and more stable in buffalo milk as compared to cow milk. However, colostrum possessed 5 times higher activity as compared to mature milk. It was also observed that various factors: parity of animal and lactation stage not influences the activity of LZ but it was increased during the peak summer and winter seasons [86-88]. A substantial increase of milk LZ in mastitis among different bovine species suggested that the neutrophils are the most probable source of LZ due to inflammation of mammary gland [89-91]

\subsection{Lactoperoxidases}

Lactoperoxidase (LP; EC 1.11.1.7) is the second most abundant enzyme after xanthine oxidase in bovine milk. The most generally prescribed industrial utilization of LP systems is the preservation of raw fresh milk during transportation and storage in dairy plants [92, 93]. It received a considerable attention as an optimum indicator of super-pasteurized milk [94]. Its level in bovine milk is about $30 \mathrm{mg} / \mathrm{L}$ constituting approximately $1 \%$ whey protein [95]. The LP system (LP-thiocyanate- $\mathrm{H}_{2} \mathrm{O}_{2}$ ) is a natural preservation system and has antimicrobial characteristics. Oxidation of thiocyanate in the presence of $\mathrm{H}_{2} \mathrm{O}_{2}$ is catalyzed by activated LP and produce hypothiocyanate (OSCN) or higher oxides (antimicrobial compounds). These compounds exhibited their antimicrobial properties by oxidizing the sulfhydryl groups of proteins to disulfides [96].

LP enzyme activities are affected by various factors, i.e., sexual cycle, season, lactation, diet, and breed [95, 97]. LP activity in bovine milk $(1.2-19.4 \mathrm{U} / \mathrm{mL})$ is about 20 times higher in peroxidase action than human milk [98]. LP levels in dairy animals milk is ranged from 1.5 to 2.7 U/mL with a general mean of $2.3 \mathrm{U} / \mathrm{mL}$ [99]. The LP level is low in colostrum of dairy animals, after that adopted inclined trend rapidly after $3-5$ days postpartum [95]. LP enzyme activity is a precursor to diagnose the mastitis disease in dairy animals. The activity of LP increases as the somatic cell count (SCC) increases [100, 101].

The LP activity of cows adopted declined trend along with lactation stages. The activity of LP decreases with the advancement in lactation stages $(9.64-6.66 \mathrm{U} / \mathrm{mL})$ [28]. The decreasing trend along with lactation stages was also observed by Althaus et al. [102] who reported significant reduction in LP activity from the early stage of lactation toward the end of lactation. Reiter [95] observed a significant increase in LP activity between 4 and 5 days after calving of the lactation 
period, followed by a gradual decrease toward close of lactation. The reduction in action of LP activity in cow milk could be due to increase in the thiocyanate content as Fonteh et al. [99] described that the LP level promoted with an increase in 2,2'- azino-bis (3-ethylbenzothiazoline-6-sulphonic acid) or ABTS contents but reduced with an increase in thiocyanate contents. They also reported that LP activity is enhanced with whey protein, lactose, magnesium, sodium, and calcium chlorides, and reduced in occurrence of casein.

\subsection{Catalases}

Catalase (CAT; $\mathrm{H}_{2} \mathrm{O}_{2}: \mathrm{H}_{2} \mathrm{O}_{2}$ oxidoreductase; EC 1.11.1.6) dismutates hydrogen peroxide $\left(\mathrm{H}_{2} \mathrm{O}_{2}\right)$ into water $\left(\mathrm{H}_{2} \mathrm{O}\right)$ and free oxygen $\left(\mathrm{O}_{2}\right)[8,103]$. CAT was among the first enzymes present in milk. Babcock and Russell [104] portrayed that an extract of separator slime can break down $\mathrm{H}_{2} \mathrm{O}_{2}$. The CAT activity in milk fluctuates with feedstuff and lactation phase, level expanded particularly during mastitis $[103,105]$. CAT has the ability to degrade the surplus hydrogen peroxide and reduce oxidative infection caused by reactive oxygen species (ROS) [106].

CAT and SCC contributed in the mastitis risk markers. Risk level of mastitis and losses in milk production increase with the advancement in parity, phase of lactation, and also in spring and winter seasons [107]. Measurement of CAT activity plays a distinct role in monitoring the health status of udders in cow. The antioxidant activity of enzyme CAT increases when SCC increases [100, 108, 109]. CAT antioxidant activity is higher in colostrum, then reductions occur as the lactation stage proceeds and again high in the late lactation [110,111]. Its absence in milk is an indication of an efficient pasteurization process [7].

\subsection{Xanthine oxidoreductase}

Xanthine oxidoreductase (XOR; EC 1.13.22; 1.1.1.204) is a milk indigenous enzyme having capability of oxidizing hypoxanthine to xanthine and xanthine to uric acid with the reduction of $\mathrm{O}_{2}$ to $\mathrm{H}_{2} \mathrm{O}_{2}$ [7, 112]. This protein is initially presented in milk; in 1902, Schardinger reported that this compound is competent for oxidizing aldehydes to acids by the lessening the methylene blue and after that generally called this chemical as "Schardinger enzyme." XOR has been established to require $\mathrm{FAD}^{+}$and $\mathrm{Mo}^{++}$for its optimum catalytic action [103, $113,114]$.

XOR is concentrated in MFGM, which is the second most abundant protein constituting, 20\% of the MFGM protein. Milk is a good source of XOR, some of its portion is shifted to mammary glands by means of the blood circulation system. The XOR level in milk differs recognizably during lactation. However, bovine milk contains significant levels of XOR (1.4-1.8 U/mg) as compared to goat $(0.27 \mathrm{U} / \mathrm{mg})$ and sheep $(0.69 \mathrm{U} / \mathrm{mg})$ milk and camel (nd) milk because enzyme molecules lack molybdenum $\left(\mathrm{Mo}^{++}\right)$[115-118]. This level can be amplified by complementing the diet with $\mathrm{Mo}^{++}$[7].

In buffalo milk, XOR $(0.75 \mathrm{U} / \mathrm{mg})$ exists in the catalytically inactive form because of higher concentration of demolybdo and desulfo forms. Structural factors and lower contents of $\mathrm{Fe} / \mathrm{S}$ might be the possible reason of lowering enzymatic activity of XOR in buffalo [119]. 
Surprisingly, camel milk exhibited no detectable XOR activity and its $\mathrm{Mo}^{++}$contents were comparable to human and goat milk [120].

Being significant part of lactating cells, the levels of XOR mRNA began to increase during midpregnancy, turned upward at the onset of lactation and diminished quickly in constrained involution [121]. XOR expression remained constant, while specific activity enhanced at the initial lactation phase that facilitates in milk synthesis [122]. Physiologically, XOR contains hydrogen peroxide, nitric oxide, and superoxide ion, mainly functions as in the activation of various metabolic pathways [123]. XOR contributes to an antimicrobial defense mechanism in the gastrointestinal tract (GIT) tract and plays a significant role in the immune system of mammary glands [111, 124, 125]. XOR activity increases during infectious diseases and its cytotoxic action is useful for the defenses against bacteria [123].

\section{Conclusions}

Conclusively, intensive review of enzyme activities has revealed the significance of indigenous milk enzymes with varied concentration behavior during lactation stages. Lactation stage has a prominent effect on enzymes activities and ultimately it may affect the technological behavior of milk composition.

Generally, colostrum formation contains higher enzyme activities than during the established lactation period. Mastitis or several other progressions that increase leukocytes in milk increase enzyme activities such as CAT. LP, ACP, and LP decrease while lipase activity increases with progress of lactation. ALP activity first increases then decreases at the end of lactation. PL activity increases in the late lactation because of that it makes milk less suitable for cheese making.

This varied behavior of enzyme activities at early, mid, and late lactation stages can be a troubling problem for manufacturing of milk and milk products in various regions of the world. As enormous animals in late lactation periods and considerable seasonal variations affect the ultimate quality of milk and have a better increased choice to process the specified valued dairy product. Furthermore, milk from mid lactation would be a balanced source of energy to maintain the health status of the individuals.

\section{Author details}

Aneela Hameed, Majid Hussain* and Saeed Akhtar

*Address all correspondence to: mhussain@bzu.edu.pk

Institute of Food Science \& Nutrition, Faculty of Agricultural Sciences, Bahauddin Zakariya University, Multan, Pakistan 


\section{References}

[1] Pehrsson P, Haytowitz D, Holden J, Perry C, Beckler D. USDA's national food and nutrient analysis program: food sampling. J. Food Compos. Anal. 2000;13:379-389. doi: 10.1006/jfca.1999.0867

[2] Nickerson S. Milk production: Factors affecting milk composition. In: Harding F, editor. Milk Quality: Springer, USA; 1995. p. 3-24. doi: 10.1007/978-1-4615-2195-2_2

[3] Misra S, Sharma A, Bhattacharya T, Kumar P, Roy S. Association of breed and polymorphism of $\alpha$ s1- and $\alpha$ s2-casein genes with milk quality and daily milk and constituent yield traits of buffaloes (Bubalus bubalis). Buffalo Bulletin. 2008;27:294-301.

[4] Fox P, Guinee T, Cogan T, McSweeney P. Fundamentals of Cheese Science. Aspen Publishers, Inc., Gaithersburg, MD; 2000.

[5] Looper ML. Factors Affecting Milk Composition of Lactating Cows. Division of Agriculture, University of Arkansas System, USA, 2012.

[6] Schutz M, Hansen L, Steuernagel G, Kuck A. Variation of milk, fat, protein, and somatic cells for dairy cattle. J. Dairy Sci. 1990;73:484-493. doi: 10.3168/ jds.S0022-0302(90)78696-1

[7] Fox P, Kelly A. Indigenous enzymes in milk: overview and historical aspects - Part 1. Int. Dairy J. 2006;16:500-516. doi: 10.1016/j.idairyj.2005.09.013

[8] Fox PF. Significance of indigenous enzymes in milk and dairy products. Food Science and Technology, Marcel Dekker, New York; 2003. pp.255-278.

[9] Kelly A, Fox P. Indigenous enzymes in milk: a synopsis of future research requirements. Int. Dairy J. 2006;16:707-715. doi: 10.1016/j.idairyj.2005.10.018

[10] Moatsou G. Indigenous enzymatic activities in ovine and caprine milks. Int. J. Dairy Technol. 2010;63:16-31. doi: 10.1111/j.1471-0307.2009.00552.x

[11] Walstra P, Jenness R. Dairy Chemistry \& Physics. John Wiley \& Sons, New York, USA; 1984.

[12] Zhao W-S, Hu S-L, Yu K, Wang H, Wang W, Loor J, Luo J. Lipoprotein lipase, tissue expression and effects on genes related to fatty acid synthesis in goat mammary epithelial cells. Int. J. Mol. Sci. 2014;15:22757-22771. doi: 10.3390/ijms151222757

[13] Beisson F, Tiss A, Rivière C, Verger R. Methods for lipase detection and assay: a critical review. Eur. J. Lipid Sci. Technol. 2000;102:133-153. doi: 10.1002/(SICI)1438-9312(200002)102:2<133::AID-EJLT133>3.0.CO;2-X

[14] Chahiniana H, Sarda L. Distinction between esterases and lipases: comparative biochemical properties of sequence-related carboxylesterases. Protein Pept. Lett. 2009;16:1149-1161. doi: 10.2174/092986609789071333 
[15] Chen L, Daniel RM, Coolbear T. Detection and impact of protease and lipase activities in milk and milk powders. Int. Dairy J. 2003;13:255-275. doi: 10.1016/ S0958-6946(02)00171-1

[16] Acton QA. Esterases-Advances in Research and Application: 2013 edition. Scholarly Editions, Atlanta, Gorgia; 2013.

[17] Fuquay JW, Fox PF, McSweeney PL. Encyclopedia of Dairy Sciences. Academic Press, San Diego; 2011. doi: 10.1016/B978-0-12-374407-4.09006-3

[18] Saito Z, Kim G. Effects of lactation stage on temperature-activated lipolysis and lipase activity in cow's milk. Japanese J. Dairy Food Sci. (Japan). 1994; 44:A139-145.

[19] Deeth H, Fitz-Gerald C. Lipolytic enzymes and hydrolytic rancidity. Advanced Dairy Chemistry Volume 2 Lipids. Springer, New York; 2006. pp. 481-556. doi: 10.1007/0-387-28813-9_15

[20] Palmquist D. Milk fat: origin of fatty acids and influence of nutritional factors thereon. Advanced Dairy Chemistry Volume 2 Lipids. Springer, New York; 2006. pp. 43-92. doi: 10.1007/0-387-28813-9_2

[21] Ahrné L, Björck L. Lipolysis and the distribution of lipase activity in bovine milk in relation to stage of lactation and time of milking. J. Dairy Res. 1985;52:55-64. doi: $10.1017 / S 002202990002389 X$

[22] Deeth HC. Lipoprotein lipase and lipolysis in milk. Int. Dairy J. 2006;16:555-562. doi: 10.1016/j.idairyj.2005.08.011

[23] Chandan R, Shahani K. Milk lipases. A review. J. Dairy Sci. 1964;47:471-480. doi: 10.3168/jds.S0022-0302(64)88694-X

[24] Egelrud T, Olivecrona T. The purification of a lipoprotein lipase from bovine skim milk. J. Biol. Chem. 1972;247:6212-6217.

[25] Toušová R, Stádník L, Ducháček J. Effect of season and the time of milking on spontaneous and induced lipolysis in bovine milk fat. Czech. J. Food Sci. 2013;31:20-26.

[26] Chilliard Y, Ferlay A, Rouel J, Lamberet G. A review of nutritional and physiological factors affecting goat milk lipid synthesis and lipolysis. J. Dairy Sci. 2003;86:1751-1770. doi: $10.3168 /$ jds.S0022-0302(03)73761-8

[27] Tarassuk N, Frankel E. The specificity of milk lipase. IV. Partition of the lipase system in milk. J. Dairy Sci. 1957;40:418-430. doi: 10.3168/jds.S0022-0302(57)94496-X

[28] Hameed A, Hussain R, Zahoor T, Akhtar S, Riaz M, Ismail T. Effect of oxytocin on enzyme activities in bovine milk. Int. Dairy J. 2014;39:229-231. doi: 10.1016/j.idairyj. 2014.06.013 
[29] Turner RB, Liu L, Sazonova IY, Reed GL. Structural elements that govern the substrate specificity of the clot-dissolving enzyme plasmin. J. Biol. Chem. 2002;277:33068-33074. doi: 10.1074/jbc.M203782200

[30] Fox P, McSweeney P. Proteolysis in cheese during ripening. Food Rev. Int. 1996;12:457509. doi: 10.1080/87559129609541091

[31] Kitchen BJ. Indigenous milk enzymes. In: Fox P, editor. Developments in Dairy Chemistry-3: Springer, Netherlands; 1985 . p. 239-279. doi: 10.1007/978-94-009-4950-8_9

[32] Ismail B, Nielsen S. Invited review: plasmin protease in milk: current knowledge and relevance to dairy industry. J. Dairy Sci. 2010;93:4999-5009. doi: 10.3168/jds.2010-3122

[33] Albenzio M, Caroprese M, Santillo A, Marino R, Muscio A, Sevi A. Proteolytic patterns and plasmin activity in ewes' milk as affected by somatic cell count and stage of lactation. J. Dairy Res. 2005;72:86-92. doi: 10.1017/S0022029904000676

[34] Bastian ED, Brown RJ. Plasmin in milk and dairy products: an update. Int. Dairy J. 1996;6:435-457. doi: 10.1016/0958-6946(95)00021-6

[35] Di Luccia A, Picariello G, Trani A, Alviti G, Loizzo P, Faccia M, Addeo F. Occurrence of $\beta$-casein fragments in cold-stored and curdled river buffalo (Bubalus bubalis L.) milk. J. Dairy Sci. 2009;92:1319-1329. doi: 10.3168/jds.2008-1220

[36] Farrell H, Jimenez-Flores R, Bleck G, Brown E, Butler J, Creamer L, Hicks C, Hollar C, $\mathrm{Ng}$-Kwai-Hang K, Swaisgood H. Nomenclature of the proteins of cows' milk-Sixth revision. J. Dairy Sci. 2004;87:1641-1674. doi: 10.3168/jds.S0022-0302(04)73319-6

[37] Kaminogawa S, Mizobuchi H, Yamauchi K. Comparison of bovine milk protease with plasmin. Agric. Biol. Chem. 1972;36:2163-2167. doi:/10.1271/bbb1961.36.2163

[38] Crudden A, Kelly AL. Studies of plasmin activity in whey. Int. Dairy J. 2003;13:987-993. doi: 10.1016/S0958-6946(03)00140-7

[39] Nielsen S. Plasmin system in milk. In: Roginski H, Fuquay J, Fox P, editors. Encyclopedia of dairy sciences. II: Bodmin, Cornwall, UK; 2003. p. 929-934. doi: 10.1016/ B0-12-227235-8/00153-X

[40] Ozen BF, Hayes KD, Mauer LJ. Measurement of plasminogen concentration and differentiation of plasmin and plasminogen using Fourier-transform infrared spectroscopy. Int. Dairy J. 2003;13:441-446. doi: 10.1016/S0958-6946(03)00055-4

[41] Nielsen SS. Plasmin system and microbial proteases in milk: characteristics, roles, and relationship. J. Agric. Food Chem. 2002;50:6628-6634. doi: 10.1021/jf0201881

[42] Crudden A, Fox F, Kelly AL. Factors affecting the hydrolytic action of plasmin in milk. Int. Dairy J. 2005;15:305-313. doi: 10.1016/j.idairyj.2004.08.008 
[43] Cortellino G, Locci F, Rampilli M. An investigation of the plasmin-plasminogen system in caprine milk and cheese. Int. Dairy J. 2006;16:619-622. doi: 10.1016/j.idairyj. 2005.11.012

[44] Politis I. The role of plasminogen activator in the bovine mammary gland. In: Mol J, Clegg R, editors. Biology of the Mammary Gland. 480: Springer, USA; 2002. p. 203-207. doi: 10.1007/0-306-46832-8_25

[45] Bastian ED, Brown RJ, Ernstrom CA. Plasmin activity and milk coagulation. J. Dairy Sci. 1991;74:3677-3685. doi: 10.3168/jds.S0022-0302(91)78557-3

[46] Leitner G, Chaffer M, Shamay A, Shapiro F, Merin U, Ezra E, Saran A, Silanikove N. Changes in milk composition as affected by subclinical mastitis in sheep. J. Dairy Sci. 2004;87:46-52. doi: 10.3168/jds.S0022-0302(04)73140-9

[47] Caroprese M, Schena L, Marzano A, Marino R, Sevi A, Albenzio M. Contribution of macrophages to plasmin activity in ewe bulk milk. Ital. J. Anim. Sci. 2007;6:545-547. doi: 10.4081/ijas.2007.1s.545

[48] Koutsouli P, Patounas G, Massouras T, Bizelis I, Politis I. Plasmin-plasminogen system and milk coagulation properties of two Greek dairy sheep breeds. Small Ruminant Res. 2015;124:89-94. doi: 0.1016/j.smallrumres.2015.01.015

[49] Bianchi L, Bolla A, Budelli E, Caroli A, Casoli C, Pauselli M, Duranti E. Effect of udder health status and lactation phase on the characteristics of Sardinian ewe milk. J. Dairy Sci. 2004;87:2401-2408. doi: 10.3168/jds.S0022-0302(04)73362-7

[50] Nicholas GD, Auldist MJ, Molan PC, Stelwagen K, Prosser CG. Effects of stage of lactation and time of year on plasmin-derived proteolytic activity in bovine milk in New Zealand. J. Dairy Res. 2002;69:533-540. doi: 10.1017/S0022029902005745

[51] Politis I, Hang KNK, Giroux R. Environmental factors affecting plasmin activity in milk. J. Dairy Sci. 1989;72:1713-1718. doi: 10.3168/jds.S0022-0302(89)79286-9

[52] Richardson B, Pearce K. Determination of plasmin in dairy products. N.Z. J. Dairy Sci. Technol. 1981;16:209-220.

[53] Hamed H, Trujillo A-J, Juan B, Guamis B, ElFeki A, Gargouri A. Interrelationships between somatic cell counts, lactation stage and lactation number and their influence on plasmin activity and protein fraction distribution in dromedary (Camelus dromedaries) and cow milks. Small Ruminant Res. 2012;105:300-307. doi: 10.1016/j.smallrumres.2012.01.002

[54] Chaiyabutr N, Thammacharoen S, Komolvanich S, Chanpongsang S. Effects of longterm administration of recombinant bovine somatotropin on the plasminogen-plasmin system and milk composition of crossbred Holstein cattle. Anim. Sci. J. 2007;78:251258. doi: 10.1111/j.1740-0929.2007.00432.x 
[55] Graham W, Kay H. Phosphorus compounds of milk. V. The phosphorus partition in milk, with preliminary observations on milk phosphatase. J. Dairy Res. 1933;5:54-62. doi: $10.1017 / S 0022029900000923$

[56] Rankin S, Christiansen A, Lee W, Banavara D, Lopez-Hernandez A. Invited review: the application of alkaline phosphatase assays for the validation of milk product pasteurization. J. Dairy Sci. 2010;93:5538-5551. doi: 10.3168/jds.2010-3400

[57] Rosenthal I, Bernstein S, Rosen B. Alkaline phosphatase activity in Penicillium roqueforti and in blue-veined cheeses. J. Dairy Sci. 1996;79:16-19. doi: 10.3168/ jds.S0022-0302(96)76328-2

[58] Silanikove N, Shapiro F. Distribution of xanthine oxidase and xanthine dehydrogenase activity in bovine milk: physiological and technological implications. Int. Dairy J. 2007;17:1188-1194. doi: 10.1016/j.idairyj.2007.03.003

[59] Babaei H, Mansouri-Najand L, Molaei M, Kheradmand A, Sharifan M. Assessment of lactate dehydrogenase, alkaline phosphatase and aspartate aminotransferase activities in cow's milk as an indicator of subclinical mastitis. Vet. Res. Commun. 2007;31:419 425. doi: 10.1007/s11259-007-3539-x

[60] Andrews A. Indigenous enzymes in milk: General introduction. In: Fox P, editor. Advanced dairy chemistry-1: Proteins. II ed: Elsevier Science Publishers; 1992. p. 286292.

[61] Fox PF, McSweeney PL. Dairy Chemistry and Biochemistry. Blackie Academic \& Professional, an imprint of Chapman \& Hall, London; 1998.

[62] Anifantakis E, Rosakis P. Alkaline phosphatase activity of sheep's milk and some factors affecting it. Egypt. J. Dairy Sci. 1983;11:173-182.

[63] Patil M, Nagvekar A, Ingole S, Bharucha S, Palve V. Somatic cell count and alkaline phosphatase activity in milk for evaluation of mastitis in buffalo. Vet. World. 2015;8:363. doi: 10.14202/vetworld.2015.363-366

[64] Haab W, Smith L. Variations in alkaline phosphatase activity of milk. J. Dairy Sci. 1956;39:1644-1650. doi: 10.3168/jds.S0022-0302(56)94905-0

[65] Banks J, Muir D. Variability of alkaline phosphatase in goat milk in relation to its use as an effective index of pasteurisation. Project S01003. Hannah Research Institute, Ayr, Scotland. 2004.

[66] Huggins C, Talalay P. Sodium phenolphthalein phosphate as a substrate for phosphatase tests. J. Biol. Chem. 1945;159:399-410.

[67] Mullen J. 427. The acid phosphatase of cows' milk: I. Some properties of the enzyme. J. Dairy Res. 1950;17:288-305. doi: 10.1017/S0022029900005847

[68] Akuzawa R, Fox PF. Acid phosphatase in cheese. Anim. Sci. J. 2004;75:385-391. doi: 10.1111/j.1740-0929.2004.00202.x 
[69] Flynn N, Akuzawa R, Fox P, editors. Characterisation of isozymes of acid phosphatase isolated from bovine milk. Abstracts 28th Food Science and Technology Research Conference. University College, Cork; 1998. p. 165.

[70] Fox P, Uniacke-Lowe T, McSweeney P, O'Mahony J. Heat-induced changes in milk. Dairy Chemistry and Biochemistry: Springer International Publishing, Switzerland; 2015. p. 345-375. doi: 10.1007/978-3-319-14892-2_9

[71] Fox PF, Morrissey PA. Indigenous Enzymes of Bovine Milk. In: Birch GG, Blakebrough N, Parker KJ, editors. Enzymes and Food Processing. 3rd ed: Springer Netherlands; 2012. p. 213-238. doi: 10.1007/978-94-011-6740-6

[72] Shakeel-ur-Rehman, Farkye NY. Enzymes indigenous to milk: phosphatase. In: Roginski H, Fuquay J, Fox P, editors. Encyclopedia of Dairy Sciences: Amsterdam Academic Press; 2002. p. 934-938. doi: 10.1016/B0-12-227235-8/00154-1

[73] Fox P, Stepaniak L. Enzymes in cheese technology. Int. Dairy J. 1993;3:509-530. doi: 10.1016/0958-6946(93)90029-Y

[74] Andrews A. Further studies on acid phosphatase of leucocyte origin in normal and mastitic bovine milks. J. Dairy Res. 1976;43:127-131. doi: 10.1017/S0022029900015673

[75] Cegielska-Radziejewska R, Lesnierowski G, Kijowski J. Properties and application of egg white lysozyme and its modified preparations - a review. Pol. J. Food Nutr. Sci. 2008;58. doi: 10.1007/s00217-010-1347-y

[76] Masschalck B, Michiels CW. Antimicrobial properties of lysozyme in relation to foodborne vegetative bacteria. Crit. Rev. Microbiol. 2003;29:191-214. doi: $10.1080 / 713610448$

[77] Wiesner J, Vilcinskas A. Antimicrobial peptides: the ancient arm of the human immune system. Virulence. 2010;1:440-464. doi: 10.4161/viru.1.5.12983

[78] Park YW, Haenlein GF. Handbook of Milk of Non-Bovine Mammals. John Wiley \& Sons, New York; 2008. doi: 10.1002/9780470999738

[79] Al-Jabri AA. Honey, milk and antibiotics. Afr. J. Biotechnol. 2005;4:1580-1587.

[80] Lönnerdal B. Nutritional and physiologic significance of human milk proteins. Am. J. Clin. Nutr. 2003;77:1537S-1543S.

[81] Maga EA, Sargent RG, Zeng H, Pati S, Zarling DA, Oppenheim SM, Collette NM, Moyer AL, Conrad-Brink JS, Rowe JD. Increased efficiency of transgenic livestock production. Transgenic Res. 2003;12:485-496. doi: 10.1023/A:1024257906647

[82] Losnedahl K, Wang H, Aslam M. Antimicrobial proteins in milk. J. Diary Sci. 1996;84:1123-1127.

[83] Król J, Litwinczuk Z, Brodziak A, Barlowska J. Lactoferrin, lysozyme and immunoglobulin $\mathrm{G}$ content in milk of four breeds of cows managed under intensive production system. Polish J. Vet. Sci. 2010;13:357-361. 
[84] Benkerroum N. Antimicrobial activity of lysozyme with special relevance to milk. Afr. J. Biotechnol. 2008;7:4856-4867.

[85] Abd El-Aziz M. Study on lysozyme level, distribution and effect of heat treatment in buffalo and cow milk. Ann. Agric. Sci. (Cairo). 2006;51:439-446.

[86] Montagne P, Cuilliere M, Mole C, Bene M, Faure G. Changes in lactoferrin and lysozyme levels in human milk during the first twelve weeks of lactation. In: Newburg D, editor. Bioactive Components of Human Milk: Springer, USA; 2001. p. 241-247. doi: 10.1007/978-1-4615-1371-1_30

[87] Hussain M, Bakalis S, Gouseti O, Zahoor T, Anjum FM, Shahid M. Dynamic and shear stress rheological properties of guar galactomannans and its hydrolyzed derivatives. Int. J. Biol. Macromol. 2015;72:687-691. doi: 10.1016/j.ijbiomac.2014.09.019

[88] Priyadarshini S, Kansal VK. Purification, characterization, antibacterial activity and Nterminal sequencing of buffalo-milk lysozyme. J. Dairy Res. 2002;69:419-431. doi: $10.1017 /$ S002202990200554X

[89] Persson K, Carlsson $\AA$, Hambleton C, Guidry A. Immunoglobulins, lysozyme and lactoferrin in the teat and udder of the dry cow during endotoxin-induced inflammation. J. Vet. Med. B. 1992;39:165-174. doi: 10.1111/j.1439-0450.1992.tb01154.x

[90] Radwan Y, Elmarimi A. The use of lysoplate test in the diagnosis of subclinical mastitis. Bull. Anim. Health. Prod. Africa. 1987;35:100-135.

[91] Ismail M, Selim S, Soliman R. Changes in lysozyme activity in milk and its significance in the diagnosis of subclinical mastitis in goats. Egypt. Vet. Med. J. 1984;32:59-65.

[92] De Wit J, Van Hooydonk A. Structure, functions and applications of lactoperoxidase in natural antimicrobial systems. Nederlands melk en Zuiveltijdschrift. 1996;50:227-244. doi: 10.1201/9781420039368.ch3

[93] Pruitt KM, Kamau DN. The lactoperoxidase system of bovine and human milk. In: DS Robinson, NAM Eskin, Editors. Oxidative Enzymes in Foods. London: Elsevier Applied Science; 1991. 133-174p

[94] Lorenzen PC, Martin D, Clawin-Rädecker I, Barth K, Knappstein K. Activities of alkaline phosphatase, $\gamma$-glutamyltransferase and lactoperoxidase in cow, sheep and goat's milk in relation to heat treatment. Small Ruminant Res. 2010;89:18-23. doi: 10.1016/j.smallrumres.2009.11.013

[95] Reiter B. The lactoperoxidase system of bovine milk. In: Pruitt K, Tenovou J, editors. The lactoperoxidase system: chemistry and biological significance: Marcel Dekker, New York, USA; 1985. p. 123-141. doi: 10.1016/B978-0-08-031739-7.50030-6

[96] Martin-Hernandez M, van Markwijk BW, Vreeman HJ. Isolation and properties of lactoperoxidase from bovine milk. Neth. Milk Dairy J. 1990;44:213-231. 
[97] Kussendrager KD, Van Hooijdonk A. Lactoperoxidase: physico-chemical properties, occurrence, mechanism of action and applications. Br. J. Nutr. 2000;84:19-25. doi: $10.1017 /$ S0007114500002208

[98] Gothefors L, Marklund S. Lactoperoxidase activity in human milk and in saliva of newborn infants. Infect. Immun. 1975;11:1210-1215.

[99] Fonteh FA, Grandison AS, Lewis MJ. Factors affecting lactoperoxidase activity. Int. J. Dairy Technol. 2005;58:233-236. doi: 10.1111/j.1471-0307.2005.00227.x

[100] Andrei S, Pintea A, Groza I, Bogdan L, Ciupe S, Matei S. Milk antioxidant enzymes activity in cows with sub clinical mastitis. Scientific Papers - Veterinary Medicine, University of Agricultural Sciences and Veterinary Medicine "Ion Ionescu de la Brad" Iaşi. 2009;52:1-6.

[101] Asadpour R, Tayefi-Nasrabadi H, Moghadam G, Nofouzi K. Correlation between lactoperoxidase activity and somatic cell count for diagnosis subclinical mastitis in early lactation of dairy cows. J. Anim. Vet. Adv. 2008;7:777-779.

[102] Althaus R, Molina M, Rodriguez M, Fernandez N. Analysis time and lactation stage influence on lactoperoxidase system components in dairy ewe milk. J. Dairy Sci. 2001;84:1829-1835. doi: 10.3168/jds.S0022-0302(01)74622-X

[103] McSweeney P, Fox P. Advanced Dairy Chemistry: Basic Aspects: Volume 1A, Proteins. 4th ed. Springer, New York, USA; 2013. doi: 10.1007/978-1-4614-4714-6

[104] Babcock SM, Russell HL. Unorganized ferments of milk: A new factor in the ripening of cheese. Fourteenth annual report of the Wisconsin agricultural experiment station. 1897;161-193.

[105] Johnson A. The composition of milk. In: Webb B, Johnson A, Alford J, editors. Fundamentals of dairy chemistry: AVI Publishing Co. Inc, Westport, CT; 1974. p. 1-57.

[106] He Z, Yu S, Mei G, Zheng M, Wang M, Dai Y, Tang B, Li N. Maternally transmitted milk containing recombinant human catalase provides protection against oxidation for mouse offspring during lactation. Free Radic. Biol. Med. 2008;45:1135-1142. doi: 10.1016/j.freeradbiomed.2008.07.019

[107] Atasever S, Erdem H. An investigation on the determination of mastitis risk levels and milk production traits in Holstein cows. J. Appl. Anim. Res. 2008;34:13-16. doi: 10.1080/09712119.2008.9706932

[108] Atasever S, Erdem H. Association of somatic cell count with catalase enzyme activity in bovine milk. Trends Anim. Vet. Sci. 2010;1:24-27.

[109] Lindmark-Månsson $\mathrm{H}$, Åkesson B. Antioxidative factors in milk. Br. J. Nutr. 2000;84:103-110. doi: 10.1017/S0007114500002324

[110] Yuksel S, Yigit AA, Cinar M, Atmaca N, Onaran Y. Oxidant and antioxidant status of human breast milk during lactation period. Dairy Sci. Technol. 2015;95:295-302. doi: 10.1007/s13594-015-0211-z 
[111] Atasever S, Erdem H, Kul E. Relationship between somatic cell count and catalase activity in raw milk of Anatolian buffaloes. Sci. Res. Essays. 2011;6:4109-4112. doi: 10.5897/SRE11.609

[112] Martin HM, Hancock JT, Salisbury V, Harrison R. Role of xanthine oxidoreductase as an antimicrobial agent. Infect. Immun. 2004;72:4933-4939. doi: 10.1128/IAI. 72.9.4933-4939.2004

[113] Harrison R. Physiological roles of xanthine oxidoreductase. Drug Metab. Rev. 2004;36:363-375. doi: 10.1081/DMR-120037569

[114] Massey V, Harris C. Milk xanthine oxidoreductase: the first one hundred years. Biochem. Soc. Trans. 1997;25:750-755. doi: 10.1042/bst0250750

[115] Pandya AJ, Khan MMH. Buffalo milk. Handbook of milk of non-bovine mammals. 2006:195-273. doi: 10.1002/9780470999738.ch8

[116] Godber BL, Schwarz G, Mendel RR, Eisenthal R, Harrison R. Molecular characterization of human xanthine oxidoreductase: the enzyme is grossly deficient in molybdenum and substantially deficient in iron-sulphur centres. Biochem. J. 2005;388:501-508. doi: 10.1042/BJ20041984

[117] Atmani D, Benboubetra M, Harrison R. Goats' milk xanthine oxidoreductase is grossly deficient in molybdenum. J. Dairy Res. 2004;71:7-13. doi: 10.1017/S0022029903006514

[118] Benboubetra M, Baghiani A, Atmani D, Harrison R. Physicochemical and kinetic properties of purified sheep's milk xanthine oxidoreductase. J. Dairy Sci. 2004;87:1580 1584. doi: 10.3168/jds.S0022-0302(04)73311-1

[119] Gadave K, Panda S, Singh S, Kalra S, Malakar D, Perugini MA. Structural and functional insights into the catalytic inactivity of the major fraction of buffalo milk xanthine oxidoreductase. PLoS One. 2014;9:1-11. doi: 10.1371/journal.pone.0087618

[120] Baghiani A, Harrison R, Benboubetra M. Purification and partial characterisation of camel milk xanthine oxidoreductase. Arch. Physiol. Biochem. 2003;111:407-414. doi: $10.3109 / 13813450312331342265$

[121] McManaman J, Palmer C, Wright R, Neville M. Functional regulation of xanthine oxidoreductase expression and localization in the mouse mammary gland: evidence of a role in lipid secretion. J. Physiol. 2002;545:567-579. doi: 10.1113/jphysiol.2002.027185

[122] Vorbach C, Scriven A, Capecchi MR. The housekeeping gene xanthine oxidoreductase is necessary for milk fat droplet enveloping and secretion: gene sharing in the lactating mammary gland. Genes Dev. 2002;16:3223-3235. doi: 10.1101/gad.1032702

[123] Battelli MG, Polito L, Bortolotti M, Bolognesi A. Xanthine oxidoreductase-derived reactive species: physiological and pathological effects. Oxid. Med. Cell Longev. 2016:18. doi: $10.1155 / 2016 / 3527579$ 
[124] Silanikove N, Shapiro F, Leitner G. Posttranslational ruling of xanthine oxidase activity in bovine milk by its substrates. Biochem. Biophys. Res. Commun. 2007;363:561-565. doi: 10.1016/j.bbrc.2007.08.188

[125] Harrison R. Milk xanthine oxidase: properties and physiological roles. Int. Dairy J. 2006;16:546-554. doi: 10.1016/j.idairyj.2005.08.016 